\title{
Thyroid Function in a Uremic Rat Model
}

\author{
EVIDENCE SUGGESTING TISSUE HYPOTHYROIDISM
}

\author{
Victoria S. Lim, Carlos Henriquez, Hisao Seo, Samuel Refetoff, and \\ Enio Martino, Renal Division, Department of Medicine, Michael Reese Hospital \\ and Medical Center, and Thyroid Study Unit, Department of Medicine, University \\ of Chicago, Chicago, Illinois 60616
}

A B S T RACT The main objective of this study was to determine whether the principal abnormality of thyroid function observed in patients with chronic renal failure, low serum triiodothyronine $\left(T_{3}\right)$ concentration, causes hypothyroidism at the tissue level. A partially nephrectomized $(\mathrm{Nx})$ uremic rat model was developed and the following parameters of thyroid function were assessed: serum total thyroxine $\left(\mathrm{TT}_{4}\right)$, total $\mathrm{T}_{3}\left(\mathrm{TT}_{3}\right)$, and thyrotropin and liver $\mathrm{T}_{3}$ content, and activity of two thyroid hormone-dependent enzymes, mitochondrial $\alpha$-glycerophosphate dehydrogenase ( $\alpha \mathrm{GPD})$ and cytosol malate dehydrogenase (MDH). The results were compared to those of intact control (C), thyroidectomized ( $\mathrm{Tx}$ ), and nephrectomized-thyroidectomized (NxTx) littermates.

Results expressed as mean $\pm \mathrm{SEM}$ showed that $\mathrm{Nx}$ rats had a fivefold increase in blood urea nitrogen, $(112 \pm 20 \mathrm{mg} / \mathrm{dl}$ in $\mathrm{Nx}$, and $22 \pm 1 \mathrm{mg} / \mathrm{dl} \mathrm{in} \mathrm{C)} \mathrm{and} \mathrm{mani-}$ fested all the changes of of thyroid function observed in uremic men, including a low serum $\mathrm{TT}_{3}$ level $(30 \pm 7$ $\mathrm{ng} / \mathrm{dl}$ in $\mathrm{Nx}$ and $50 \pm 6 \mathrm{ng} / \mathrm{dl}$ in $\mathrm{C})$. In the liver, $\mathrm{T}_{3}$ was significantly reduced $(18 \pm 2 \mathrm{ng} /$ total liver in $\mathrm{Nx}$ and $35 \pm 3 \mathrm{ng} /$ total liver in $\mathrm{C}$ ) as well as the activities of $\alpha \mathrm{GPD}(8.8 \pm 1.0$ and $16.1 \pm 1.5 \Delta \mathrm{OD} / \mathrm{min}$ per total liver in $\mathrm{Nx}$ and $\mathrm{C}$, respectively) and MDH $(6.3 \pm 1.6$ and $12.6 \pm 2.2 \mathrm{U} /$ total liver in $\mathrm{Nx}$ and $\mathrm{C}$, respectively). The reduction in liver enzyme activities correlated significantly with the decrease in $T_{3}$ content.

The changes in $\mathrm{T} x$ rats were as expected, showing a profound reduction in serum hormone levels, liver $T_{3}$ content, and liver enzyme activities. Serum thyrotropin was markedly elevated to $2,390 \pm 212 \mathrm{ng} / \mathrm{ml}$ as compared to $703 \pm 61$ in $\mathrm{C}$ and $441 \pm 87 \mathrm{ng} / \mathrm{ml}$ in $\mathrm{Nx}$ rats.

This work was presented in part at the 12th Annual Meeting of the American Society of Nephrology, Boston, 18-20 November 1979, and the 8th International Thyroid Conference, Sydney, Australia, 3-8 February 1980.

Received for publication 7 February 1980 and in revised form 20 June 1980.
The NxTx rats showed the combined effects of nephrectomy and thyroidectomy; blood urea nitrogen was elevated to 203 , and serum levels of $\mathrm{TT}_{4}, \mathrm{TT}_{3}$, and thyrotropin were $0.4,<10$, and 2,525 , respectively. Total liver $\mathrm{T}_{3}$ and $\alpha \mathrm{GPD}$ and MDH were strikingly low; the corresponding values were $3.5,2.4$, and 2.5 .

L-triiodothyronine replacement $(0.4 \mu \mathrm{g} / 100 \mathrm{~g}$ body $w t / d)$ for 4 wk in the $\mathrm{Nx}$ rats resulted in significant increases in liver enzyme activities, $\alpha \mathrm{GPD}$ and $\mathrm{MDH}$ rose by 70 and $60 \%$ over their respective basal values without alteration in the severity of azotemia.

From these data, we conclude that the reduction of liver $\mathrm{T}_{3}$ content in the uremic rats, accompanied by a decrease in $\alpha$ GPD and MDH activity, indicates the presence of hypothyroidism at the tissue level. Restoration of enzyme activities toward normal levels after $\mathrm{T}_{3}$ administration provided further supporting evidence that the diminution in liver enzyme activity was causally related to tissue $T_{3}$ deficiency.

\section{INTRODUCTION}

Patients with chronic renal failure have low serum levels of total triiodothyronine $\left(\mathrm{TT}_{3}\right)^{1}$ due, in part, to a defect in the peripheral conversion of thyroxine $\left(T_{4}\right)$ to triiodothyronine $\left(T_{3}\right)(1-11)$. However, the physiologic significance of the low serum $\mathrm{T}_{3}$ concentration in a variety of conditions (4-6), including uremia, has not been clearly defined. Thus, the question of whether uremic patients are hypothyroid remains unanswered. Investigators who propose that uremic patients are euthyroid base their conclusion on the observation that serum thyrotropin (TSH) is not elevated and thyroid

\footnotetext{
${ }^{1}$ Abbreviations used in this paper: BUN, blood urea nitrogen; C, control; $\mathrm{FT}_{4} \mathrm{I}_{\mathrm{x}}$, free thyroxine index; GPD, glycerophosphate dehydrogenase; $\mathrm{MDH}$, malate dehydrogenase; $\mathbf{N x}$, nephrecotomized; NxTx, nephrectomized-thyroidectomized; $\mathrm{T}_{3}$, triiodothyronine; $\mathrm{T}_{4}$, thyroxine; $\mathrm{TSH}$, thyrotropin; $\mathrm{TT}_{3}$, total $\mathrm{T}_{3} ; \mathrm{TT}_{4}$, total $\mathrm{T}_{4} ; \mathrm{Tx}$, thyroidectomized.
} 
function tests, independent of hormone measurements such as the basal metabolic rate, the systolic time interval, and the deep tendon reflex relaxation time, are normal (7). The argument for hypothyroidism is purely theoretical and is based on the concept that $T_{3}$ is the hormone through which the major metabolic effects of $\mathrm{T}_{4}$ are exerted $(12,13)$. The absence of TSH elevation should not be regarded as unequivocal evidence of euthyroidism because disturbances in the hypothalamicpituitary axis are known to occur in uremia (1417). The controversy regarding thyroid status in uremia is partly because most studies have concentrated on the measurement of thyroid hormone in serum. There is no information available on the content of $T_{3}$ in tissues. This is important because the bulk of extrathyroidal $\mathrm{T}_{3}$ is generated in the peripheral tissues, at the sites of action $(12,13)$.

We studied thyroid function in a uremic rat model. $\mathrm{T}_{3}$ concentrations in serum as well as in liver were measured. In addition, the activities of two liver enzymes regulated by thyroid hormone (18-21), mitochondrial $\alpha$-glycerophosphate dehydrogenase ( $\alpha \mathrm{GPD}$ ) and cytosol malate dehydrogenase (MDH), were determined. The results showed an early reduction in liver $\mathrm{T}_{3}$ content accompanied by a significant diminution in both enzyme activities. These data, coupled with the correction of the observed enzyme deficiencies after $\mathrm{T}_{3}$ treatment, suggest that hypothyroidism at the tissue level accompanies the uremic state.

\section{METHODS}

\section{Experimental design}

Four groups of rats, control (C), thyroidectomized (Tx), nephrectomized $(\mathrm{Nx})$, and nephrectomized-thyroidectomized (NxTx), were examined. The $\mathrm{Nx}$ rats were studied 4, 5, and 6 wk after nephrectomy. Male Sprague Dawley rats, weighing $120-150 \mathrm{~g}$ at the start of each experiment, were obtained from Animal Resource Laboratory, Madison, Wis. Uremic rats were prepared by a two-stage $5 / 6$ nephrectomy. The upper and lower poles of the left kidney were removed by ligation and the raw surfaces were cauterized to prevent bleeding and minimize compensatory hypertrophy. The entire right kidney was removed 5-7 d later. Only $50-60 \%$ of the $N x$ rats were used; $30-40 \%$ died within $72 \mathrm{~h}$ of the second stage of nephrectomy and another $10 \%$ were discarded because blood urea nitrogen (BUN) was insufficiently elevated $(<50 \mathrm{mg} / \mathrm{dl})$. Thyroidectomy was performed by a standard surgical technique. Mortality in the Tx group was negligible and hypothyroidism always ensued. In the NxTx rats, thyroidectomy was done $5 \mathrm{wk}$ after nephrectomy. As these rats appeared very ill, studies were performed 3-5 d after thyroidectomy. The mortality in this group was $\sim 75 \%$. About $70 \%$ survived the second stage of nephrectomy but only $25 \%$ survived the subsequent thyroidectomy. Unless otherwise specified, rats were fed regular chow and given access to tap water ad lib. Tx and NxTx rats were given $0.9 \%$ calcium chloride as the drinking water. In addition, NxTx rats received $10 \mathrm{mg}$ of calcium gluconate, by intraperitoneal injection, every other day after thyroidectomy.

In another experiment, only $\mathrm{C}$ and 6-wk $\mathrm{Nx}$ rats were used.
Each group was further divided in half; one-half received no treatment whereas the other received exogenous L-triidothyronine (Sigma Chemical Co., St. Louis, Mo.) supplement at $\mathbf{0 . 4}$ $\mu \mathrm{g} / 100 \mathrm{~g}$ of body $w \mathrm{t} / \mathrm{d}$ by intraperitoneal injections for 4 consecutive wk starting 2 wk after the second stage of nephrectomy. The dose was considered to be optimal for $T_{3}$ replacement based on the studies by Garcia et al. (22) on the effect of $\mathrm{T}_{3}$ on $\mathrm{TSH}$ response to $\mathrm{TSH}$-releasing hormone in $\mathrm{Tx}$ rats.

Rats were killed by cardiac exsanguination under light ether anesthesia. The liver was perfused in situ with normal saline solution until light tan. The entire liver was removed and weighed. $1 \mathrm{~g}$ was frozen on dry ice immediately and kept at $-30^{\circ} \mathrm{C}$ until extraction was done on another day for measurement of $\mathrm{T}_{3}$ content. Additionally, 1 gram of liver was processed freshly for quantitation of mitochondrial $\alpha$ GPD activity and another $2 \mathrm{~g}$ for determination of MDH activity. The two kidneys of $\mathrm{C}$ and $\mathrm{Tx}$ rats and the kidney remnants of $\mathrm{Nx}$ and NxTx rats were removed and weighed. Serum was saved for measurements of BUN, total thyroxine $\left(\mathrm{TT}_{4}\right)$, free thyroxine index $\left(\mathrm{FT}_{4} \mathrm{I}_{\mathrm{x}}\right), \mathrm{T}_{4}$ binding capacity, $\mathrm{TT}_{3}$, and thyroid stimulating hormone (TSH). In the rats that received exogenous $\mathrm{T}_{3}$ treatment, additional serum samples were obtained $2 \mathrm{~h}$ after the last $T_{3}$ injection for determination of $\mathrm{TT}_{3}$ levels.

As serum thyroid hormone concentrations (23) and $\alpha$ GPD and MDH activities (24) vary with age, littermates were used for each experiment. Execution of surgical procedures was staggered so that rats in each experimental group were of the same age at the time of study.

\section{Analytical procedures}

Determination of $T_{3}$ content. Liver $T_{3}$ was extracted using the method of Nejad et al. (25). Briefly, $1 \mathrm{~g}$ of frozen liver was homogenized in $2 \mathrm{ml}$ of chilled water containing $50 \mu \mathrm{M}$ propylthiouracil. $10 \mu \mathrm{l}$ of the homogenate was saved for protein determination and the remainder was extracted twice with 6 $\mathrm{ml}$ of $95 \%$ ethanol. An equal volume of chloroform (12 ml) was added to the pooled ethanol extract placed in a separatory funnel. $\mathrm{T}_{3}$ was extracted from the ethanol-chloroform mixture using $1 / 3 \mathrm{vol}$ of $2 \mathrm{~N} \mathrm{NH}_{4} \mathrm{OH}$ three times. The pooled aqueous phase was concentrated in a flash evaporator and subsequently lyophilized. The residue was reconstituted in $0.5 \mathrm{M}$ phosphate buffer containing $1 \%$ bovine serum albumin, $\mathrm{pH}$ 7.5 , and was stored at $-20^{\circ} \mathrm{C}$ until analyzed for $\mathrm{T}_{3}$ content.

Recovery was monitored in every batch of $\mathrm{T}_{3}$ extraction by addition of sufficient ${ }^{[25} \mathrm{I}^{12} \mathrm{~T}_{3}$ to a second $1 \mathrm{~g}$ piece of liver before extraction and corrections for recovery were carried out for each sample.

Assessment of enzyme activity. Mitochondrial $\alpha$ GPD (EC 1.1.1.8) activity was measured in the mitochondrial fraction prepared from $1 \mathrm{~g}$ of freshly perfused liver. Homogenization was done in $9 \mathrm{vol}$ of $0.25 \mathrm{M}$ sucrose, $50 \mathrm{mM}$ Tris- $\mathrm{HCl}, \mathrm{pH}$ 7.5. After centrifugation at $1,000 \mathrm{~g}, 4^{\circ} \mathrm{C}$ for $10 \mathrm{~min}$, the supernate was again centrifuged at $12,000 \mathrm{~g}, 4^{\circ} \mathrm{C}$ for $10 \mathrm{~min}$, and the resultant pellet containing mitochondria was resuspended in 1 $\mathrm{ml}$ of $0.125 \mathrm{M}$ phosphate buffer, $\mathrm{pH}$ 7.5. $\alpha$ GPD activity was analyzed in triplicate (three sets of blanks and samples) according to the method of Lee and Lardy (19). Reactions were carried out for $15 \mathrm{~min}$. The difference in the mean optical density in the assay tubes and in the blanks read at $500 \mathrm{~nm}(\Delta O D)$ and the protein concentration, measured in an aliquot of the mitochondrial preparation, was used for the calculation of the enzyme activity expressed as $\triangle O D$ per minute per total liver and per $\mathrm{mg}$ of protein.

Cytosol MDH (EC 1.1.1.40) activity was measured in $2 \mathrm{~g}$ of fresh liver. Homogenization was done in 3 vol of chilled 0.25 $M$ sucrose. The homogenate was centrifuged at $9,000 \mathrm{~g} 4^{\circ} \mathrm{C}$ for $10 \mathrm{~min}$, and the supernate was recentrifuged at $100,000 \mathrm{~g}$, 
$4^{\circ} \mathrm{C}$ for $60 \mathrm{~min}$. This supernate, containing the cytosol fraction, was passed through a $0.22 \mu$ Millipore filter (Millipore Corp., Bedford, Mass.) and diluted 5- or 10-fold with a solution containing $10 \mathrm{mM}$ EDTA, $50 \mathrm{mM}$ Tris $\mathrm{HCl}, 200 \mathrm{mM}$ magnesium acetate, and $2 \mathrm{mM} 2$-mercaptoethanol, pH 7.4. MDH activity was then measured using the method of Ochoa (26) as modified by Hsu and Lardy (27), by monitoring the reduction of NADP to NADPH, producing changes in the optical density at $340 \mathrm{~nm}$. Appropriate blanks, without added substrate, and a standard preparation of purified chicken liver enzyme (Sigma Chemical Co., St. Louis, Mo.) were used in each assay. Enzyme activity was expressed as units of MDH per milligram of cytosol protein and per total liver.

Other measurements. Serum $\mathrm{TT}_{4}$ was measured by a competitive binding assay and the results of a resin $\mathrm{T}_{4}$ uptake test were used to calculate $\mathrm{FT}_{4} \mathrm{I}_{\mathrm{x}}$ as described (28).

Serum and tissue $T_{3}$ were measured by a radioimmunoassay (29) using a specific antiserum, a gift from Dr. G. Burke (Cook County Hospital, Chicago, Ill.). Determinations in serum were carried out in the presence of 8-anilino-1-naphthalene sulfonic acid and those in tissues were done in the absence of this substance. Corresponding standard curves contained hypothyroid rat serum or buffer only. The sensitivity of the assay was $10 \mathrm{ng} / \mathrm{dl}$ and the intra- and interassay coefficients of variation were 7 and $15 \%$, respectively.
Serum $\mathrm{T}_{4}$ binding capacity was measured by saturation (30) and expressed as percent of control.

Serum TSH was measured by a radioimmunoassay (31) using materials from two kits (Nos. 3 and 4) obtained from $\mathrm{Na}$ tional Institute of Arthritis Metabolism and Digestive Diseases. The assay sensitivity was $100 \mathrm{ng} / \mathrm{ml}$. The intra- and interassay coefficients of variation were 3.1 and $16.4 \%$, respectively.

The BUN was determined by the standard microcolorimetric technique with diacetyl monoxime and ferric nitrate reagents.

Protein concentration was measured using the method of Lowry (32).

Statistical analyses, including Student's $t$ test, analysis of variance, and linear regression analysis, were done by using the Biomedical Computer Program package (Health Science Computer Facility, University of California, Los Angeles, Calif.). Group data are presented as mean \pm SEM.

\section{RESULTS}

Kidney and thyroid function of all groups of rats are compared in Table I. After nephrectomy, mean BUN in the $\mathrm{Nx}$ rats increased fivefold and the mean weight

TABLE I

Thyroid and Renal Function in $C, T x, N x$, and NxTx Rats

\begin{tabular}{|c|c|c|c|c|c|c|c|c|}
\hline & \multirow{2}{*}{$\begin{array}{l}\text { Body } \\
\text { weight }\end{array}$} & \multirow{2}{*}{$\begin{array}{l}\text { Kidney } \\
\text { weight }\end{array}$} & \multirow{2}{*}{$\begin{array}{c}\text { Liver } \\
\text { weight }\end{array}$} & \multirow[b]{2}{*}{ BUN } & \multicolumn{4}{|c|}{ Serum } \\
\hline & & & & & TT, & $\mathrm{FT}_{\mathbf{f}} \mathbf{I}_{\mathrm{x}}$ & $\mathrm{TT}_{3}$ & TSH \\
\hline & $g$ & $g$ & $g$ & $m g / d l$ & $\mu g / d l$ & & $n g / d l$ & $n g / m l$ \\
\hline$C(11)$ & $\begin{array}{r}373 \\
\pm 12\end{array}$ & $\begin{array}{r}2.8 \\
\pm 0.1\end{array}$ & $\begin{array}{r}14.5 \\
\pm 0.9\end{array}$ & $\begin{array}{r}22 \\
\pm 1\end{array}$ & $\begin{array}{r}4.7 \\
\pm 0.3\end{array}$ & $\begin{array}{r}6.3 \\
\pm 0.4\end{array}$ & $\begin{array}{r}52 \\
\pm 6\end{array}$ & $\begin{array}{r}703 \\
\pm 61\end{array}$ \\
\hline $\begin{array}{l}\mathrm{Tx}(8) \\
P\end{array}$ & $\begin{array}{c}349 \\
\pm 8 \\
\text { NS }\end{array}$ & $\begin{array}{r}2.1 \\
\pm 0.1 \\
<0.001\end{array}$ & $\begin{array}{r}11.6 \\
\pm 0.6 \\
<0.02\end{array}$ & $\begin{array}{r}28 \\
\pm 2 \\
<0.001\end{array}$ & $\begin{array}{r}0.4 \\
\pm 0.1 \\
<0.001\end{array}$ & $\begin{array}{r}0.4 \\
\pm 0.1 \\
<0.001\end{array}$ & $\begin{array}{r}18 \\
\pm 2 \\
<0.001\end{array}$ & $\begin{array}{r}2249 \\
\pm 136 \\
<0.001\end{array}$ \\
\hline $\begin{array}{l}\text { Nx4 (14) } \\
P\end{array}$ & $\begin{array}{r}283 \\
\pm 13 \\
<0.001\end{array}$ & $\begin{array}{r}1.1 \\
\pm 0.1 \\
<0.001\end{array}$ & $\begin{array}{c}12.6 \\
\pm 0.6 \\
\text { NS }\end{array}$ & $\begin{array}{c}112 \\
\pm 11 \\
<0.001\end{array}$ & $\begin{array}{r}3.5 \\
\pm 0.3 \\
<0.01\end{array}$ & $\begin{array}{r}4.7 \\
\pm 0.4 \\
<0.02\end{array}$ & $\begin{array}{c}43 \\
\pm 4 \\
\text { NS }\end{array}$ & $\begin{array}{r}510 \\
\pm 58 \\
<0.05\end{array}$ \\
\hline $\begin{array}{l}\text { Nx5 (12) } \\
P\end{array}$ & $\begin{array}{c}276 \\
\pm 13 \\
<0.001\end{array}$ & $\begin{array}{r}1.0 \\
\pm 0.1 \\
<0.001\end{array}$ & $\begin{array}{c}12.1 \\
\pm 0.8 \\
\text { NS }\end{array}$ & $\begin{array}{c}113 \\
\pm 10 \\
<0.001\end{array}$ & $\begin{array}{r}3.3 \\
\pm 0.3 \\
<0.01\end{array}$ & $\begin{array}{r}4.6 \\
\pm 0.5 \\
<0.02\end{array}$ & $\begin{array}{c}44 \\
\pm 5 \\
\text { NS }\end{array}$ & $\begin{array}{r}383 \\
\pm 56 \\
<0.001\end{array}$ \\
\hline Nx6 (11) & $\begin{array}{r}256 \\
\pm 25 \\
<0.001\end{array}$ & $\begin{array}{r}1.1 \\
\pm 0.1 \\
<0.001\end{array}$ & $\begin{array}{c}12.6 \\
\pm 0.8 \\
\text { NS }\end{array}$ & $\begin{array}{r}112 \\
\pm 20 \\
<0.001\end{array}$ & $\begin{array}{r}3.3 \\
\pm 0.4 \\
<0.01\end{array}$ & $\begin{array}{r}4.6 \\
\pm 0.6 \\
<0.02\end{array}$ & $\begin{array}{r}30 \\
\pm 7 \\
<0.02\end{array}$ & $\begin{array}{r}441 \\
\pm 87 \\
<0.02\end{array}$ \\
\hline $\begin{array}{l}\text { NxTx (6) } \\
P\end{array}$ & $\begin{array}{r}173 \\
\pm 8 \\
<0.001\end{array}$ & $\begin{array}{r}0.8 \\
\pm 0.1 \\
<0.001\end{array}$ & $\begin{array}{r}8.0 \\
\pm 0.2 \\
<0.001\end{array}$ & $\begin{array}{c}203 \\
\pm 24 \\
<0.001\end{array}$ & $\begin{array}{r}0.4 \\
\pm 0.2 \\
<0.001\end{array}$ & $\begin{array}{r}0.5 \\
\pm 0.2 \\
<0.001\end{array}$ & $\begin{array}{l}<10 \\
\pm 0 \\
-\end{array}$ & $\begin{array}{r}2525 \\
\pm 292 \\
<0.001\end{array}$ \\
\hline $\begin{array}{l}\mathrm{DF}^{*} \\
\mathrm{~F} \text { ratio } \\
P\end{array}$ & $\begin{array}{c}5 / 56 \\
17.909 \\
<0.0001\end{array}$ & $\begin{array}{c}5 / 56 \\
63.226 \\
<0.0001\end{array}$ & $\begin{array}{c}5 / 56 \\
6.37 \\
<0.0001\end{array}$ & $\begin{array}{c}5 / 56 \\
22.171 \\
<0.0001\end{array}$ & $\begin{array}{c}5 / 56 \\
31.334 \\
<0.0001\end{array}$ & $\begin{array}{c}5 / 56 \\
28.535 \\
<0.0001\end{array}$ & $\begin{array}{c}5 / 56 \\
9.747 \\
<0.0001\end{array}$ & $\begin{array}{c}5 / 56 \\
83.906 \\
<0.0001\end{array}$ \\
\hline
\end{tabular}

All values are given as mean $\pm \mathrm{SEM}$. (Nx), 4, 5 , and 6 indicate weeks postnephrectomy. The number of rats per group is in parenthesis. The significance of the difference between the means of each experimental group and the control was assessed by the Student's $t$ test.

* Individual values from all six groups were tested by the analysis of variance; DF, the degree of freedom, $F$ ratio, and $P$ values are listed. 
of the kidney remnant was $<40 \%$ of the combined kidney weights of the control littermates. Mean body weight was also decreased by $\sim 30 \%$. The postnephrectomy hypertrophy of the kidney appeared to have been completed during the first 4 wk after the second stage operation as there was no difference in either the mean kidney weights or the mean BUN levels among the 4-, 5-, and 6-wk $\mathrm{Nx}$ rats. Thyroid function also differed significantly in the $\mathrm{Nx}$ rats. Mean serum $\mathrm{TT}_{4}$ and $\mathrm{FT}_{4} \mathrm{I}_{\mathrm{x}}$ were decreased by $\sim 30 \% 4 \mathrm{wk}$ postnephrectomy and remained stable during the subsequent $2 \mathrm{wk}$ of observation. Serum $\mathrm{T}_{4}$ binding capacity was not affected by nephrectomy, being $98 \pm 6 \%$ in the 6 -wk $\mathrm{Nx}$ rats as compared to $100 \pm 4 \%$ in the $C$ group. The mean serum $\mathrm{TT}_{3}$ showed a declining trend during the 4th and 5th wk, but the level became significantly reduced to $30 \mathrm{ng} /$ $\mathrm{dl}$ at $6 \mathrm{wk}$ postnephrectomy. Mean serum TSH concentrations were significantly lower in all three $\mathrm{Nx}$ rat groups. The $T x$ rats showed changes typical of severe hypothyroidism: mean serum $\mathrm{TT}_{4}$ and $\mathrm{FT}_{4} \mathrm{I}_{\mathbf{x}}$ were reduced to $<10 \%$, mean serum $\mathrm{TT}_{3}$ to about $35 \%$, and mean serum TSH increased by $300 \%$ of control littermates. The slight but significantly elevated BUN in the Tx rats is consistent with the known effect of thyroid hormone in augmenting glomerular filtration rate (33). The NxTx rats showed the combined effects of nephrectomy and thyroidectomy. Mean serum $\mathrm{TT}_{4}$ and $\mathrm{FT}_{4} \mathrm{I}_{\mathrm{x}}$ were reduced to the same extent as the $\mathrm{Tx}$ littermates, but the reduction in serum $\mathrm{TT}_{3}$ to $<10 \mathrm{ng} / \mathrm{dl}$ was more severe than could be accounted for by thyroidectomy alone. Mean serum TSH was elevated to a comparable degree as in the $\mathrm{Tx}$ rats. When compared to $\mathrm{Nx}$ rats, NxTx rats had a mean BUN level twofold higher, and the kidney remnant weighed an average of $20 \%$ less. These rats generally appeared very ill and their mean body weight was $40 \%$ less than the nonthyroidectomized uremic rats.

$\mathrm{T}_{3}$ content and the activity of the two thyroid-hormone dependent enzymes in the liver are summarized in Table II. Nephrectomy resulted in a significant reduction in liver $\mathrm{T}_{3}$ content as well as the activities of the thyroid hormone-dependent enzymes. Mean total

TABLE II

Liver $T_{3}$ Content, Mitochondrial $\alpha G P D$, and Cytosol MDH Activities in C, Tx, Nx, and NxTx Rats

\begin{tabular}{|c|c|c|c|c|c|c|c|}
\hline & \multicolumn{3}{|c|}{$T_{3}$} & \multicolumn{2}{|c|}{$\alpha G P D$} & \multicolumn{2}{|c|}{ MDH } \\
\hline & $\begin{array}{c}\text { ng/total } \\
\text { liver }\end{array}$ & $n g / g$ & $\begin{array}{c}p g / m g \\
\text { protein }\end{array}$ & $\begin{array}{l}\Delta O D / \min / \\
\text { total liver }\end{array}$ & $\begin{array}{l}\Delta O D / m i n / \\
m g \text { protein }\end{array}$ & $\begin{array}{c}\text { units/total } \\
\text { liver }\end{array}$ & $\begin{array}{c}\text { units } / m g \\
\text { protein }\end{array}$ \\
\hline$C(11)$ & $\begin{array}{r}35.4 \\
\pm 3.1\end{array}$ & $\begin{array}{r}2.47 \\
\pm 0.21\end{array}$ & $\begin{array}{r}19 \\
\pm 1\end{array}$ & $\begin{array}{r}16.13 \\
\pm 1.54\end{array}$ & $\begin{array}{r}1.700 \\
\pm 0.139\end{array}$ & $\begin{array}{r}12.64 \\
\pm 2.21\end{array}$ & $\begin{array}{r}0.037 \\
\pm 0.003\end{array}$ \\
\hline $\begin{array}{l}\mathrm{Tx}(8) \\
P\end{array}$ & $\begin{array}{r}5.3 \\
\pm 0.9 \\
<0.001\end{array}$ & $\begin{array}{r}0.45 \\
\pm 0.05 \\
<0.001\end{array}$ & $\begin{array}{c}4 \\
\pm 0.4 \\
<0.001\end{array}$ & $\begin{aligned} 5.07 \\
\pm 0.62 \\
<0.01\end{aligned}$ & $\begin{array}{r}0.595 \\
\pm 0.055 \\
<0.001\end{array}$ & $\begin{array}{r}5.76 \\
\pm 1.15 \\
<0.05\end{array}$ & $\begin{array}{r}0.019 \\
\pm 0.002 \\
<0.001\end{array}$ \\
\hline $\begin{array}{l}\mathrm{Nx} 4(14) \\
P\end{array}$ & $\begin{array}{c}28.8 \\
\pm 3.1 \\
\text { NS }\end{array}$ & $\begin{array}{c}2.32 \\
\pm 0.20 \\
\text { NS }\end{array}$ & $\begin{array}{l}20 \\
\pm 0.2 \\
\text { NS }\end{array}$ & $\begin{array}{r}10.70 \\
\pm 0.86 \\
<0.01\end{array}$ & $\begin{aligned} & 1.351 \\
& \pm 0.107 \\
& \text { NS }\end{aligned}$ & - & - \\
\hline $\begin{array}{l}\mathrm{N} 55(12) \\
P\end{array}$ & $\begin{array}{r}20.5 \\
\pm 3.5 \\
<0.01\end{array}$ & $\begin{array}{r}1.62 \\
\pm 0.19 \\
<0.01\end{array}$ & $\begin{array}{c}13 \\
\pm 2 \\
<0.01\end{array}$ & $\begin{array}{r}10.29 \\
\pm 1.03 \\
<0.01\end{array}$ & $\begin{aligned} & 1.268 \\
\pm & 0.092 \\
< & 0.02\end{aligned}$ & - & - \\
\hline $\begin{array}{l}\mathrm{Nx6}(11) \\
P\end{array}$ & $\begin{array}{r}18.5 \\
\pm 2.4 \\
<0.001\end{array}$ & $\begin{array}{r}1.45 \\
\pm 0.14 \\
<0.001\end{array}$ & $\begin{array}{c}12 \\
\pm 1 \\
<0.001\end{array}$ & $\begin{array}{r}8.77 \\
\pm 1.00 \\
<0.001\end{array}$ & $\begin{array}{r}1.061 \\
\pm 0.101 \\
<0.001\end{array}$ & $\begin{array}{r}6.26 \\
+1.59 \\
<0.05\end{array}$ & $\begin{aligned} & 0.024 \\
\pm & 0.003 \\
< & 0.02\end{aligned}$ \\
\hline $\operatorname{NxTx}(6)$ & $\begin{array}{r}3.5 \\
\pm 0.3 \\
<0.001\end{array}$ & $\begin{array}{r}0.44 \\
\pm 0.04 \\
<0.001\end{array}$ & $\begin{array}{c}5 \\
\pm 0.4 \\
<0.001\end{array}$ & $\begin{array}{r}2.36 \\
\pm 0.27 \\
<0.001\end{array}$ & $\begin{array}{r}0.646 \\
\pm 0.123 \\
<0.001\end{array}$ & $\begin{array}{r}2.48 \\
\pm 0.15 \\
<0.005\end{array}$ & $\begin{array}{r}0.020 \\
\pm 0.001 \\
<0.001\end{array}$ \\
\hline $\begin{array}{l}\mathrm{DF}^{*} \\
\mathrm{~F} \text { ratio } \\
P\end{array}$ & $\begin{array}{c}5 / 56 \\
16.641 \\
<0.0001\end{array}$ & $\begin{array}{c}5 / 56 \\
18.109 \\
<0.0001\end{array}$ & $\begin{array}{c}5 / 56 \\
15.84 \\
<0.0001\end{array}$ & $\begin{array}{c}5 / 56 \\
17.854 \\
<0.0001\end{array}$ & $\begin{array}{c}5 / 56 \\
14.05 \\
<0.0001\end{array}$ & $\begin{array}{c}3 / 22 \\
9.148 \\
<0.0005\end{array}$ & $\begin{array}{c}3 / 22 \\
11.837 \\
<0.0005\end{array}$ \\
\hline
\end{tabular}

All values are represented as means \pm SEM. $(\mathrm{Nx}) 4,5$, and 6 refer to weeks postnephrectomy. The number of rats per group is in parenthesis. The significance of the difference between the means of each experimental group and the control was assessed by the Student $t$ test.

* Individual values from all six groups were tested by the analysis of variance; DF, the degree of freedom, $\mathrm{F}$ ratio, and $P$ values are summarized. 
liver $T_{3}$ content and total liver mitochondrial $\alpha$ GPD activity were reduced on the fourth week; the decrease became statistically significant on the 5th wk and further declined on the 6th wk postnephrectomy. Results are similar when expressed in terms of total tissue or mitochondrial protein concentration. Cytosol MDH activity was examined only in the 6-wk $\mathrm{Nx}$ rats; both total liver $\mathrm{MDH}$ and $\mathrm{MDH} / \mathrm{milligrams}$ of cytosol protein were significantly reduced. The changes after Tx were as expected: liver $\mathrm{T}_{3}$ and $\alpha \mathrm{GPD}$ and $\mathrm{MDH}$ activities were all markedly reduced. In the $\mathrm{NxTx}$ rats, mean liver weight was $\sim 50 \%$ that of control rats so that total liver $\mathrm{T}_{3}$ content and total liver enzyme activities were further decreased to levels lower than either $\mathrm{Tx}$ or $\mathrm{Nx}$ alone. As the protein concentration in the liver and the subcellular fractions were also greatly reduced, $\mathrm{T}_{3}$ content and enzyme activities in this group of rats when corrected for protein concentration werêt reduced to the same level as in the Tx littermates.

It appeared that the reduction in $\alpha \mathrm{GPD}$ and $\mathrm{MDH}$ activities in the $\mathrm{Nx}$ rats correlated best with the reduction in liver $\mathrm{T}_{3}$ content (Figs. 1 and 2). Significant positive correlations were found when the $\mathrm{Nx}$ rats were examined independently of the $\mathrm{C}$ and $\mathrm{Tx}$ rats. There was no significant difference when the two regression lines were compared. Control rats having higher $\mathrm{T}_{3}$ content and greater enzyme activities were grouped in the upper section whereas the $T x$ rats with the least amount

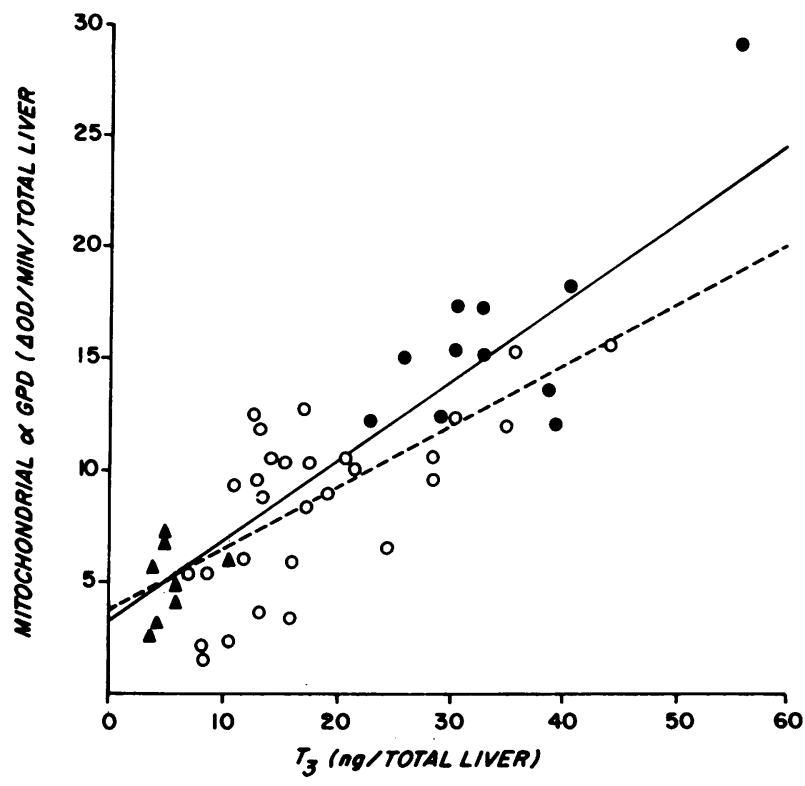

FIgURE 1 Correlation between total liver $T_{3}$ and total liver mitochondrial $\alpha$ GPD. Two linear regression lines are presented. The solid line was derived from $C(\Theta)$ and $T x(\Delta)$ rats $(n=19, r=0.896$, and $P<0.01)$. The dotted line was constructed from 5- and 6-wk $\mathrm{Nx}(O)$ rats $(n=29, r=0.666$, and $P<0.01)$. There is no statistical difference between the two lines.

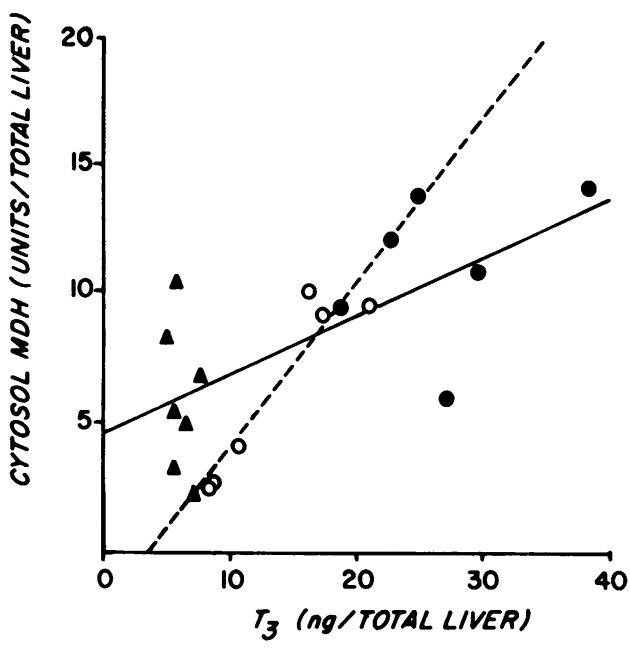

FIGURE 2 Total liver cytosol MDH was plotted as a function of total liver $T_{3}$ showing excellent correlations between these two parameters. The solid line $(n=13, r=0.688$, and $P<0.01$ ) was derived from $\mathrm{C}(\Theta)$ and $\mathrm{Tx}(\Delta)$ rats, whereas the dotted line $(n=6, r=0.946$, and $P<0.01)$ was based on the data of 6-wk $\mathrm{Nx}(\mathrm{O})$ rats. The two regression lines are not different statistically.

of $T_{3}$ and the lowest enzyme activities were tightly packed in the left lower corner. The $\mathrm{N}_{\mathrm{x}}$ rats having intermediary values were scattered in between.

The effects of $\mathrm{T}_{3}$ treatment in the $\mathrm{Nx}$ rats are depicted in Figs. 3 and 4. Both $\mathrm{C}$ and 6-wk Nx rats were either not treated or given $0.4 \mu \mathrm{g} \mathrm{T}_{3} / 100 \mathrm{~g}$ of body wt by daily intraperitoneal injections for 4 consecutive wk starting 2 wk after nephrectomy. In both groups of rats, mean serum $\mathrm{TT}_{3}$ concentration increased to 185 and 180 $\mathrm{ng} / \mathrm{dl}$, respectively, $2 \mathrm{~h}$ after $\mathrm{T}_{3}$ injection and serum TSH was suppressed to levels $<100 \mathrm{ng} / \mathrm{ml}$. Mean concentrations of BUN were not changed by $\mathrm{T}_{3}$ treatment. At the tissue level, $T_{3}$ treatment did not significantly alter the mean $\mathrm{T}_{3}$ content, $\alpha \mathrm{GPD}$, or MDH activities of the $\mathrm{C}$ rats. The only change was an increase in the specific activity of $\alpha \mathrm{GPD}$. In the $\mathrm{Nx}$ rats, changes were more apparent. Total liver $\alpha$ GPD and MDH rose by 70 and $60 \%$ over their respective base-line values. These increases became more significant when corrected for protein concentration. In fact, the reduced enzyme activities of $\mathrm{Nx}$ rats were normalized to values comparable to untreated controls. These changes in enzyme activities were in agreement with the corresponding normalization of the liver $T_{3}$ content, which rose from 12 to $17 \mathrm{pg} / \mathrm{mg}$ protein. Other important information not shown in the figures is that of body weights and serum $\mathrm{TT}_{4}$. Despite improvement in thyroid function, $T_{3}$ treatment had no beneficial effect on body weight, which was $340 \pm 8 \mathrm{~g}$ in $\mathrm{C}$ and $251 \pm 13 \mathrm{~g}$ in $\mathrm{Nx}$ rats $(P<0.001)$. Mean serum $\mathrm{TT}_{4}$ was decreased in both groups of $\mathrm{T}_{3}$ treated rats, being $2.5 \pm 0.2 \mu \mathrm{g} / \mathrm{dl}$ in the $\mathrm{C}$ and $1.5 \pm 0.2 \mu \mathrm{g} / \mathrm{dl}$ in the $\mathrm{Nx}$ rats $(P<0.001)$. 


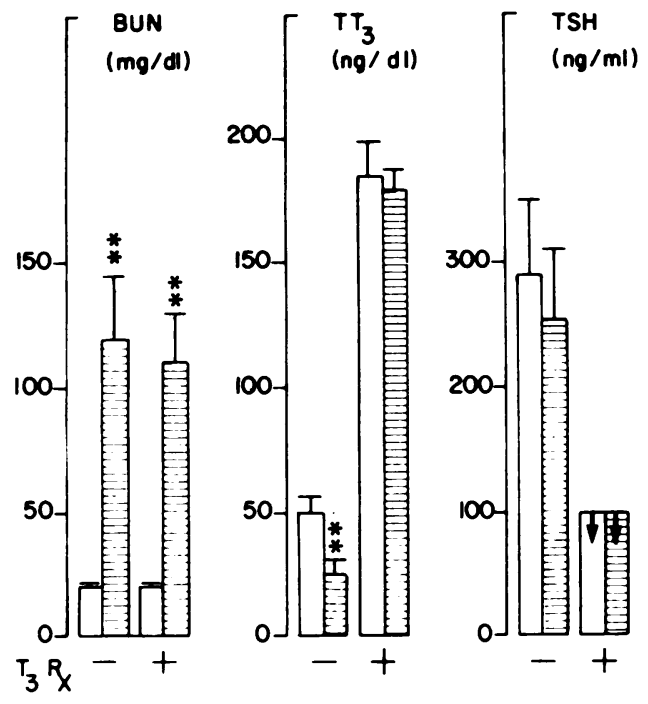

FIGURE 3 Effect of $T_{3}$ treatment on renal and thyroid function in $C(\square)$ and $N x($ 目) rats. Values, representing mean $\pm S E M$, are depicted for nontreated $(-)$ and treated $(+)$ rats. Treatment consisted of $0.4 \mu \mathrm{g} \mathrm{T}_{3} / 100 \mathrm{~g}$ body wt per day given by intraperitoneal injection for $4 \mathrm{wk}$. Statistically significant differences between control and nephrectomized rats were indicated by ${ }^{* *}, P<0.005$ to $<0.0005$ using one-tailed $t$ test. Mean serum $\mathrm{TT}_{4}(\mu \mathrm{g} / \mathrm{dl})$ levels were $2.5 \pm 0.2$ and $1.5 \pm 0.2$, respectively, for the treated $\mathrm{C}$ and treated $\mathrm{Nx}$ rats. Data for untreated groups are in Table I.

\section{DISCUSSION}

The main objective of this study was to examine the physiologic significance of the principal abnormality associated with chronic renal failure, low serum $\mathrm{T}_{3}$ concentration (1, 4-9), by searching for evidence of hypothyroidism at the tissue level. We attempted to answer the question by quantitation of $T_{3}$ content in the liver and by measurement of the activities of two thyroid hormone-dependent hepatic enzymes. A uremic rat model produced by a two-stage $5 / 6$ nephrectomy was developed. After an initial $30 \%$ loss of body weight, a stable and reproducible form of chronic azotemia was achieved with a five- to sixfold elevation of BUN during the entire period of observation. More importantly, the uremic rat exhibited changes of thyroid function typical of man with chronic renal failure (1-11) and thus constituted a suitable experimental model. There was a slight decrease in serum $\mathrm{TT}_{4}, \mathrm{FT}_{4} \mathrm{I}_{\mathrm{x}}$, and a marked diminution in serum $\mathrm{TT}_{3}$ concentration; serum $\mathrm{TSH}$ level was normal or slightly reduced (Table I). In the NxTx rats, serum $\mathrm{TT}_{4}$ and $\mathrm{FT}_{4} \mathrm{I}_{\mathrm{x}}$ were decreased to the same extent as in the $\mathrm{Tx}$ rats, but serum $\mathrm{TT}_{3}$ was reduced to a greater degree. This observation indicated that the low serum $\mathrm{TT}_{3}$ in NxTx rats is not only due to lack of $\mathrm{T}_{4}$ but also to an impairment in $T_{4}$ to $T_{3}$ conversion caused by uremia.

An important finding in this study was a reduction in liver $\mathrm{T}_{3}$ content in the $\mathrm{Nx}$ rats. The decrease was most marked when expressed as $T_{3}$ content per total liver, an average of $50 \%$ of the control values $6 \mathrm{wk}$ after nephrectomy (Table II). The reduction in liver $\mathrm{T}_{3}$ was also significant when expressed as nanograms per milligram protein. It is unlikely that the decrease in liver $\mathrm{T}_{3}$ is due to a lack of $\mathrm{T}_{4}$ as serum $\mathrm{TT}_{4}$ was only slightly

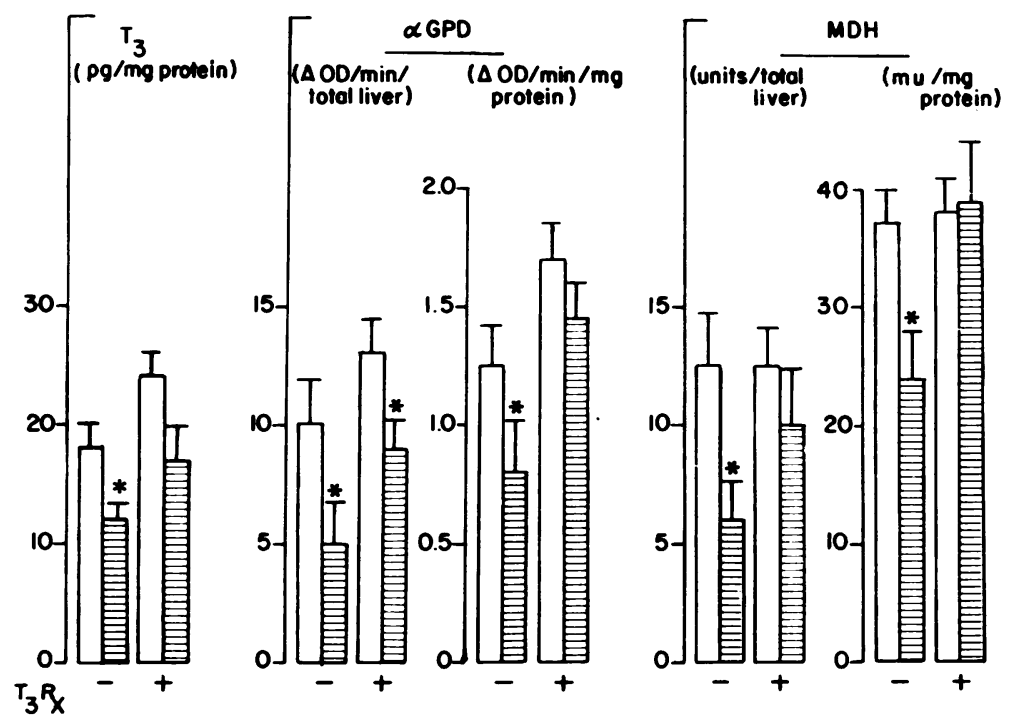

FIGURE 4 Effect of $\mathrm{T}_{3}$ treatment on liver $\mathrm{T}_{3}$ and $\alpha$ GPD and MDH activities in $\mathrm{C}(\square)$ and Nx (目) rats. Values, representing mean $\pm S E M$, are depicted for nontreated $(-)$ and treated $(+)$ rats. The treated-rats were given $0.4 \mu \mathrm{g} \mathrm{T}_{3} / 100 \mathrm{~g}$ body wt per day by intraperitoneal injection for 4 wk. $\alpha \mathrm{GPD}$ and $\mathrm{MDH}$ are presented both as total activity for liver and as specific activity (corrected for protein concentration). Statistically significant differences between $\mathrm{C}$ and $\mathrm{Nx}$ rats are indicated by ${ }^{*}$, $P<0.05$ to $<0.025$ using one-tailed $t$ test. 
reduced. Moreover, while the reduction in serum $\mathrm{TT}_{4}$ occurred early and remained stable, a significant decrease in liver $\mathrm{T}_{3}$ was not noted until $5 \mathrm{wk}$ after nephrectomy with further diminution at $6 \mathrm{wk}$. Using isotopically labeled $T_{4}$ and $T_{3}$ we have previously shown that uremic patients have impaired ability in $T_{4}$ to $T_{3}$ conversion (9), a mechanism most likely responsible for the low liver $\mathrm{T}_{3}$ content in the present experimental model. Reduction in tissue $T_{3}$ content is not unique to uremia; starvation and partial hepatectomy in the rat have been shown to produce a decresae in nuclear $T_{3}$ binding capacity and $\mathrm{T}_{3}$ content $(34,35)$. In humans, Reichlin et al. (36) found decreased $T_{3}$ concentration in liver and kidney obtained at necropsy from patients who died from a variety of chronic illnesses.

$\mathrm{T}_{3}$ concentration in the liver was several times higher than that in the serum and reduction in liver $T_{3}$ content preceded the appearance of significant diminution in serum $\mathrm{T}_{3}$ concentration. Whereas the finding of low tissue $T_{3}$ content is not necessarily indicative of hypothyroidism, the concomitant reduction of mitochondrial $\alpha G P D$ and cytosol MDH in the Nx rats suggested the presence of metabolic consequences of $T_{3}$ deficiency. As shown in Fig. 1, changes in $\alpha$ GPD paralleled those of $\mathrm{T}_{3}$ content. A similar correlation was found between the MDH activity and liver $\mathrm{T}_{3}$ content in the 6-wk $\mathrm{Nx}_{\mathrm{x}}$ rats (Fig. 2). The linear regressions correlating liver enzyme activities and $T_{3}$ content were not different in azotemic rats when compared to $T x$ and $C$ rats with intact renal function.

It is unlikely that starvation was responsible for the reduction in enzyme activities in the uremic rat as enzymes were restored to normal despite failure of these animals to achieve a higher body weight during the 4-wk period of $T_{3}$ replacement. The possibility that metabolic consequences directly related to uremia, rather than reduced $T_{3}$ supply, were responsible for the observed enzymatic changes, was considered. In fact, although thyroid hormone replacement in the $\mathrm{Tx}$ rats is known to correct the activity of these two liver enzymes (20), it has been shown that the apparently $T_{3}$ deficient severely starved and partially hepatectomized rats are resistant to the induction of liver MDH by thyroid hormone (35). Relative resistance of the starving rat to a single dose of $\mathrm{T}_{3}$ by augmentation in resting oxygen consumption has also been demonstrated (37). Nevertheless, chronic administration of physiologic doses of $T_{3}$ prevented the diminution of $\alpha$ GPD and MDH activities seen in the uremic rat. Such an observation underscores the causal relationship between tissue $T_{3}$ and enzyme induction in this animal model, especially when the increase in enzyme activities was associated with a repletion of $T_{3}$ content (Fig. 4). The slightly higher liver $T_{3}$ content in the $C$ rats given $T_{3}$ is either due to a more efficient endogenous generation of $T_{3}$ from the residual nonsuppressible $\mathrm{T}_{4}$ in these rats or, alternatively, to abnormal catabolism of $\mathrm{T}_{3}$ in the $\mathrm{Nx}$ rats. It is important to note that although $\mathrm{T}_{3}$ treatment prevented the decline in liver enzyme activity in the uremic rat, it had no effect on the magnitude of weight loss or the degree of uremia associated with nephrectomy.

Although these data clearly indicate that the reduction of liver $\alpha \mathrm{GPD}$ and MDH activities in uremia is causally related to tissue $T_{3}$ deficiency, they are in apparent contradiction with results reported in the starving and partially hepatectomized rats, models bearing similarities with the uremic rat. The resistance to $T_{3}$ in the starving and partially hepatectomized rats was manifested by the failure to observe an increase in MDH but not $\alpha$ GPD activity after the administration of a single pharmacologic dose of $\mathrm{T}_{3}(35)$. Unlike uremic and hypothyroid rats (20), basal enzyme activity in these acute experimental models was not decreased (35). No resistance to $T_{3}$ was observed in fasting human subjects with low serum $\mathrm{TT}_{3}$ when the hormone was given chronically and in physiologic doses (38).

The lack of TSH elevation in the presence of tissue hypothyroidism and low serum levels of $\mathrm{TT}_{3}$ and $\mathrm{TT}_{4}$ in the uremic rats is puzzling. It certainly could not be attributable to low TSH reserve in the pituitary as serum TSH in the NxTx rats reached levels as high as in the nonuremic $\mathrm{Tx}$ rats (Table I). It is possible that intrapituitary $T_{3}$ content is normal in the uremic rats as monodeiodination of $\mathrm{T}_{3}$ tends to be more efficient in the pituitary $(39,40)$. In such an instance, hypothyroidism would only be confined to the peripheral tissue, including the liver. Alternatively, there may be concomitant disturbances in the hypothalamic-pituitary axis with regard to TSH secretion associated with uremia. Impaired TSH response to TSH-releasing hormone is well documented in patients with chronic renal failure $(8,9)$. A resetting of the feedback regulation of TSH secretion at a lower level, proposed as the mechanism responsible for the failure to observe serum TSH elevation in response to starvation-induced decrease in $\mathrm{T}_{3}$ generation in man (38), may also be operational in the uremic rat model.

In summary, the partially nephrectomized rat was an excellent experimental model to examine thyroid function in renal failure because uremia was chronic and stable and the changes in thyroid hormone profile in the circulation were surprisingly similar to that found in patients with chronic renal failure. In this model, $\mathrm{T}_{3}$ content was markedly reduced and the $\alpha$ GPD and MDH activities were also significantly decreased. These data were interpreted as evidence consistent with hypothyroidism at the tissue level. Restoration of enzyme activity after $T_{3}$ treatment lent further support to this hypothesis. The physiologic significance of these findings with regard to total body economy and energy metabolism remains to be elucidated. 


\section{ACKNOWLEDGMENTS}

We appreciate the advice and encouragement of Dr. Leslie DeGroot and Dr. Fredric L. Coe. We thank Mr. Swen R. Hagen for his technical assistance and Ms. Amy Strauss for her help in statistical analysis.

The work was supported by U. S. Public Health Service grants HD 10918 and AM 15070 and by the Michael Reese Research Institute.

\section{REFERENCES}

1. Silverberg, D. S., R. A. Ulan, D. M. Fawcett, J. B. Dorsetor, M. Grace, and K. Bettcher. 1973. Effects of chronic hemodialysis on thyroid function in chronic renal failure. Can. Med. Assoc. J. 109: 282-286.

2. Ramirez, G., W. Jubiz, C. F. Gutch, H. A. Bloomer, R. Siegler, and W. J. Koff. Thyroid abnormalities in renal failure. 1973. Ann. Intern. Med. 79: 500-504.

3. Joasoo, A., I. P. C. Murray, J. Parkin, M. R. Robertson and D. Jeremy. 1974. Abnormalities of in vitro thyroid function tests in renal disease. Q.J. Med. 43: 245-261.

4. Carter, J. N., C. J. Eastman, J. M. Corcoran, and L. Lazarus. 1974. Effect of severe chronic illness on thyroid function. Lancet. II: 971-974.

5. Chopra, I. J., U. Chopra, S. R. Smith, M. Reza, and D. H. Solomon. 1975. Reciprocal changes in serum concentration of 3,3',5'-triiodothyronine (reverse $T_{3}$ ) and 3,3',5triiodothyronine $\left(\mathrm{T}_{3}\right)$ in systemic illnesses. J. Clin. Endocrinol. Metab. 41: 1043-1049.

6. Bermudez, F., M. I. Surks, and J. H. Oppenheimer. 1975. High incidence of decreased serum triiodothyronine concentration in patients with nonthyroidal disease. $J$. Clin. Endocrinol. Metab. 41: 27-40.

7. Spector, D. A., P. J. Davis, J. H. Helderman, B. Bell, and R. D. Utiger. 1976. Thyroid function and metabolic state in chronic renal failure. Ann. Intern. Med. 85: 724-730.

8. Ramirez, G., W. O'Neil, Jr., W. Jubiz, and H. A. Bloomer. 1976. Thyroid dysfunction in uremia: Evidence for thyroid and hypophyseal abnormalities. Ann. Intern. Med. 84: 672-676.

9. Lim, V. S., V. S. Fang, A. I. Katz, and S. Refetoff. 1977. Thyroid dysfunction in chronic renal failure. A study of the pituitary-thyroid axis and peripheral turnover kinetics of thyroxine and triiodothyronine. J. Clin. Invest. 60 $522-534$.

10. Dandona, P., D. Newton, and M. M. Platts. 1977. Longterm hemodialysis and thyroid function. Br. Med. J. 1: $134-136$.

11. Hershman, J. M., L. G. Krugman, J. D. Kopple, A. W. Reid, M. Azukizawa, and J. H. Schinaberger. 1978. Thyroid function in patients undergoing maintenance hemodialysis: unexplained low serum thyroxine. Metab. Clin. Exp. 27: 755-759.

12. Braverman, L. E., S. H. Ingbar, and K. Sterling. 1970. Conversion of thyroxine $\left(T_{4}\right)$ to triiodothyronine $\left(T_{3}\right)$ in athyreotic human subjects. J. Clin. Invest. 49: 855-864.

13. Surks, M. I., and J. H. Oppenheimer. 1977. Concentration of L-thyroxine and L-triiodothyronine specifically bound to nuclear receptors in rat liver and kidney. Quantitative evidence favoring a major role of $T_{3}$ in thyroid hormone action. J. Clin. Invest. 60: 555-562.

14. Lim, V. S., and V. S. Fang. 1975. Gonadal dysfunction in uremic men: a study of the hypothalamo-pituitary axis before and after renal transplantation. Am. J. Med. 58: $655-662$

15. Lim, V. S., S. C. Kathpalia, and L. A. Frohman. 1979. Hyperprolactinemia and impaired pituitary response to suppression and stimulation in chronic renal failure: Reversal following transplantation. J. Clin. Endocrinol. Metab. 48: $101-107$.

16. Sievertsen, G., V. S. Lim, C. Nakawatase, and L. A. Frohman. 1980. Metabolic clearance and secretion rates of human prolactin in normal subjects and in patients with chronic renal failure. J. Clin. Endocrinol. Metab. 50: 846-852.

17. Lim, V. S., C. Henriquez, G. Sievertsen, and L. A. Frohman. 1980. Ovarian function in chronic renal failure: evidence suggesting hypothalamic anovulation. Ann. Intern. Med. 93: 21-27.

18. Ruegamer, W. R., W. W. Westerfeld, and D. A. Richert 1964. $\alpha$-Glycerophosphate dehydrogenase response to thyroxine in thyroidectomized, thiouracil-fed and temperature adapted rats. Endocrinology. 75: 908-916.

19. Lee, Y. P., and H. A. Lardy. 1965. Influence of thyroid hormones on $\mathrm{L}$ - $\alpha$-glycerophosphate dehydrogenase and other dehydrogenases in various organs of the rat. J. Biol. Chem. 240: 1427-1436.

20. Oppenheimer, J. H., E. Silva, H. L. Schwartz, and M. I. Surks. 1977. Stimulation of hepatic mitochondrial $\alpha$ glycerophosphate dehydrogenase and malic enzyme by L-triiodothyronine. J. Clin. Invest. 59: 517-527.

21. Goodridge, A. G. 1976. Regulation of the synthesis of malic enzyme by thyroid hormone in liver cells in culture. In Thyroid Research. Proceedings of the VII International Thyroid Conference. J. Robbins and L. E. Braverman, editors. Excerpta Medica, Amsterdam. 355-358.

22. Garcia, M. D., F. Escobar del Rey, and G. Morreale de Escobar. 1976. Thyrotropin-releasing hormone and thyroid hormone interactions on thyrotropin secretion in the rat: lack of inhibiting effects of small doses of triiodoL-thyronine in the hypothyroid rat. Endocrinology. 98: 203-213.

23. Sewell, D. L., and B. S. Wostmann. 1975. Thyroid function and related hepatic enzymes in the germfree rat. Metab. Clin. Exp. 24: 695-701.

24. Schwartz, H. L., M. A. Forciea, C. N. Mariash, and J. H. Oppenheimer. 1979. Age-related reduction in response of hepatic enzymes to $3,5,3$ '-triiodothyronine administration. Endocrinology. 105: 41-46.

25. Nejad, I., J. Bollinger, M. A. Mitnick, P. Sullivan, and S. Reichlin. 1975. Measurement of plasma and tissue triiodothyronine concentration in the rat by radioimmunoassay. Endocrinology. 96: 773-780.

26. Ochoa, S. 1955. Malic enzymes. Methods Enzymol. 1: 739-753.

27. Hsu, R. Y., and H. A. Lardy. 1969. Malic enzymes. Methods Enzymol. 13: 230-235.

28. Robin, N. I., S. R. Hagen, F. Collaco, S. Refetoff, and H. A. Selenkow. 1971. Serum tests for measurements of thyroid function. Hormones (Basel). 2: 266-279.

29. Fang, V. S., and S. Refetoff. 1974. Radioimmunoassay for serum triiodothyronine $\left(T_{3}\right)$ : evaluation of simple techniques to control interference from binding proteins. Clin. Chem. 20: 1150-1157.

30. Refetoff, S., S. R. Hagen, and H. A. Selenkow. 1972. Estimation of the $T_{4}$ binding capacity of serum TBG and TBPA by a single $\mathrm{T}_{4}$ load ion exchange resin method. $\mathrm{J}$. $\mathrm{Nucl}$. Med. 13: 2-12.

31. Reichlin, S., J. B. Martin, R. L. Boshaus, D. S. Schalch, J. G. Pierce, and J. Bollinger. 1971. Measurement of TSH in plasma and pituitary of the rat by a radioimmunoassay utilizing bovine TSH: effect of thyroidectomy or thyroxine administration on plasma TSH level. Endocrinology. 87: 1022-1031.

32. Lowry, D. H., N. H. Rosebrough, H. L. Farr, and R. J. 
Rondale. 1951. Protein measurement with the Folin phenol reagent. J. Biol. Chem. 193: 265-275.

33. Michael, U. F., R. L. Barenberg, R. Chavez, C. A. Vaamonde, and S. Papper. 1972. Renal handling of sodium and water in the hypothyroid rat. J. Clin. Invest. 51: 1405-1415.

34. DeGroot, L. J., A. H. Coleoni, P. A. Rue, H. Seo, E. Martino, and S. Refetoff. 1977. Reduced nuclear triiodothyronine receptors in starvation-induced hypothyroidism. Biochem. Biophys. Res. Commun. 79: 173-178.

35. Dillmann, W. H., H. L. Schwartz, and J. H. Oppenheimer. 1978. Selective alterations in hepatic enzyme response after reduction of nuclear triiodothyronine receptor sites by partial hepatectomy and starvation. Biochem. Biophys. Res. Commun. 80: 259-266.

36. Reichlin, S., J. Bollinger, I. Nejad, and P. Sullivan. 1973. Tissue thyroid hormone concentration of rat and man determined by radioimmunoassay: biologic significance. Mt. Sinai J. Med. 40: 502-510.

37. Wimpfheimer, C., E. Saville, M. J. Voirol, E. Dauforth, Jr., and A. G. Burger. 1979. Starvation-induced decreased sensitivity of resting metabolic rate to triiodothyronine. Science (Wash. D. C.). 205: 1272-1273.

38. Gardner, D. F., M. M. Kaplan, C. A. Stanley, and R. D. Utiger. 1979. Effect of triiodothyronine replacement on the metabolic and pituitary responses to starvation. $N$. Engl. J. Med. 300: 579-584.

39. Silva, J. E., and P. R. Larsen. 1977. Pituitary nuclear 3,5,3'-triiodothyronine and thyrotropin secretion: an explanation for the effect of thyroxine. Science (Wash. D. C.). 198: 617-618.

40. Silva, J. E., T. E. Dick, and P. R. Larsen. 1978. The contribution of local tissue thyroxine monodeiodination to the nuclear 3,5,3'-triiodothyronine in pituitary, liver, and kidney of euthyroid rats. Endocrinology. 103: 1196-1207. 